\title{
Feelings of nurses in the reception and risk classification evaluation in the emergency room
}

\author{
Sentimentos de enfermeiros no acolhimento e na avaliação da classificação de risco em \\ pronto-socorro
}

Andressa Midori Sakai ${ }^{1}$, Mariana Angela Rossaneis ${ }^{1}$, Maria do Carmo Fernandez Lourenço Haddad ${ }^{1}$, Denise da Silva Scaneiro Sardinha ${ }^{2}$

Objective: to reveal feelings of nurses who host with risk assessment and classification in an emergency room of a pubic hospital. Methods: it is a qualitative research approach with 12 nurses interviewed. The data were analyzed, categorized and discussed according to the theoretical framework of work psychodynamics. Results: the nurses expressed feelings of satisfaction in meeting the user needs assistance. They reported feeling as fear, stress and fatigue due to the sharp pace of work, gaps in health care network and situations of violence. They highlighted coping strategies to reduce the burden of this assignment, how to share the completion of the screening with the nursing staff. Conclusion: the host with risk assessment and classification favors the autonomy of nurses and provide greater accountability to this professional users, but the limitations of available resources to solve the complaint of patients generate physical and psychological burden to this worker.

Descriptors: User Embracement; Emotions; Occupational Health; Working Conditions.

Objetivo: desvelar sentimentos de enfermeiros que realizam o acolhimento com avaliação e classificação de risco em um pronto-socorro de um hospital púbico. Métodos: pesquisa qualitativa em que foram entrevistados 12 enfermeiros, os dados foram analisados, categorizados e discutidos segundo o referencial teórico da Psicodinâmica do Trabalho. Resultados: os enfermeiros manifestaram sentimentos de satisfação em suprir as necessidades assistências do usuário. Relataram sentir medo, estresse e cansaço devido ao ritmo acentuado de trabalho, falhas na rede de atenção a saúde e situações de violência. Destacaram estratégias de enfrentamento para reduzir a sobrecarga dessa atribuição, como partilhar a realização da triagem com os técnicos de enfermagem. Conclusão: 0 acolhimento com avaliação e classificação de risco favorece a autonomia do enfermeiro e proporciona maior responsabilização desse profissional com os usuários, porém as limitações de recursos disponíveis para resolver a queixa dos pacientes geram sobrecarga física e psíquica a este trabalhador. Descritores: Acolhimento; Emoções; Saúde do Trabalhador; Condições de Trabalho.

\footnotetext{
${ }^{1}$ Universidade Estadual de Londrina. Londrina, PR, Brazil.

${ }^{2}$ Universidade Estadual de Maringá. Maringá, PR, Brazil.

Corresponding author: Andressa Midori Sakai

Av do Café, 170, Apto 23 Bloco C, CEP: 86038-000. Londrina, PR, Brazil. E-mail: andressasakai@hotmail.com
} 


\section{Introduction}

The Health System consists of a policy based on guidelines of integrality, universality, and equity, seeking to add new technologies and knowledge. Since its implementation, many advances and achievements have been made aimed at improving the care model of organization of the Brazilian public health ${ }^{(1)}$.

Urgent and emergency services are units that people seek to access the health care network, characterized by many users as the gateway to the National Health System due to delays in acquiring the necessary resources to health care delivery. This reality results in overcrowding of these services and can lead to fragmentation of care, disarticulation of care, dissatisfaction among users and professionals and hence physical and mental burden on the worker ${ }^{(2)}$.

The Ministry of Health developed the National Humanization Policy of Care and Management, HumanizaSUS, also called the National Humanization Policy in 2003 to improve the quality of health care provided to users and working conditions in urgent and emergency services. This policy is guided by the values of autonomy and the role of users, establishing solidarity ties, building networks of cooperation and collective participation in the management process $^{(1)}$.

One of the guidelines of the National Humanization Policy provides for the implementation of the host with risk assessment and classification of urgent and emergency services to accommodate and meet in a humane way users demand according to the risk assessment and also provide improvements in working conditions to address the need for discussions about ambience and paid care ${ }^{(3)}$.

Thus, the hosting strategy assessment and risk classification are to reorganize the urgent and emergency services and also the prioritization and service agility of users who have more severe medical conditions, as well as offering access referenced to other levels of care. Thus, hosting with risk assessment and classification can not be developed in isolation, building links between the services that make up the health care network, necessary to contribute to greater coordination and resolution of actions in these institutions ${ }^{(3)}$.

Due to the care and management role that nurses perform in urgent and emergency services, this professional is primarily responsible for the implementation and realization of the hosting in most emergency rooms ${ }^{(4)}$. However, there are many skills required for this activity, with numerous psychological pressures and tensions experienced daily, directly interfering with mental health worker ${ }^{(5)}$.

However, the work of professionals in the hosting with risk assessment and classification not only generates suffering, because this tool provides greater autonomy of nurses in the care organization in urgent and emergency services. Thus, the performance of this activity can be a source of comfort and professional satisfaction that positively contributes to the feeling of pleasure and favors the psychic balance of the worker, as they have linked the possibility of collective work, relief from pain and save lives, beyond professional recognition ${ }^{(5)}$.

Such ways of suffering expression and pleasure derived from the individual's insertion in the work environment are related to the psychodynamics of work. This refers to the study of psychoactive movements generated by the evolution of conflicts between the actual organization of work and the prescribed organization ${ }^{(6)}$. For the psychodynamics of work, the work is considered a form of physical, psychological and social survival, as well as a means of ensuring the identity of the individual and lead values. Thus, the work can be understood in a positive or negative way in the life of professional, correlating the context and the institutional organization ${ }^{(6)}$.

In this context, it is considered important to develop a study to examine the practice of nurses who perform the hosting to the risk assessment and classification considering the theoretical framework of psychodynamic of work ${ }^{(6)}$. For this author the work psychodynamic studies start from the understanding 
that suffering is part of the work since there is an irreducible gap between the prescribed and the real, which means that the individual faces unforeseen that put before the risk failure. Also, the worker seeks to subvert the pain into pleasure by the suffering caused by the emotional experience of failure ${ }^{(7)}$.

This study aimed to reveal the feelings of nurses who perform the hosting with risk assessment and classification in an emergency room of a pubic hospital.

\section{Methods}

This is a qualitative study. The study setting was an emergency room of medium complexity public hospital located in the state of Paraná. In the service there are, 7,300 users per month assisted on average, sent by the Emergency System for Mobile Service or the Integrated Trauma Care and Emergency and people by spontaneous demand, accounting for over $85.0 \%$ of treated cases $^{(8)}$.

The inclusion criteria in the research were to be a nurse in the emergency room and operating in the hosting area with risk assessment and classification for at least six months, not be in license provided in the data collection period. Thus, 15 nurses met the proposed criteria, and 12 agreed to participate.

Data collection took place between November 2013 to January 2014, conducted through semistructured interviews with the following question: What are the feelings you experience when performing the hosting with risk assessment and classification in this institution? Interviews were conducted in a private hospital room, with an average duration of 50 minutes.

Data were recorded and later submitted to content analysis, developed in three phases: preanalysis, analytical description and interpretation framework ${ }^{(9)}$. In the first phase, the intense reading material and organization of the interviews was conducted. Subsequently, it proceeded exploitation of testimonials for coding and categorizing. Finally, the data were interpreted according to the theoretical framework of psychodynamic of work ${ }^{(6)}$.

The names have been replaced by the letter E (nurse: E1, E2 ...) to maintain the anonymity of the participants. The study complied with the formal requirements contained in the national and international standards of regulatory research involving human beings.

\section{Results}

The nurses who perform the host to the risk assessment and classification, aged between 27 and 50 years old and eight were female. The service in the institution ranged from three to five years. Moreover, of the 12 interviewed nurses, 11 were postgraduates, of which seven of them were specialists in emergency care.

During the analysis of the transcribed interviews, reports of three categories emerged: The pleasure that practice in the host with risk assessment and classification gives to nurses; Causes of suffering of nurses in the context of host with risk assessment and classification; Strategies to deal with the suffering of nurses who perform the host with risk assessment and classification.

\section{The pleasure that practices in the host with risk assessment and classification gives nurses}

For some of the participants nurses of the research, the host with risk assessment and classification is associated with feelings of pleasure, to conduct an effective hosting through active listening to the patient's complaint and to help meet their health needs, as seen in the following speeches: I have feelings of personal satisfaction, by hosting the patient and hearing his complaint (E01). I like to perform this activity, talking, guide the patient; it is an activity in which I feel accomplished. I think I talk excessively because it takes me, I complain the patient who smokes and is diabetic, but I like it because I can prioritize what matters (E07). I like being the host, check what is going on and if I can help at that time (E08). 
It was also found that nurses had pleasure in performing nursing care during the user evaluation and expedite the service of those more severe: Once the patient was admitted to the oxygen saturation of $66 \%$ and then headed to the emergency room and he was intubated and transferred, the feeling was good because the service was performed correctly (E01). The host is the first contact of the patient with the health professional, it is a very important moment, because we will know the patient, he will know our work, and we will carry out the risk assessment which is very important, this is really the priority, to assist with greater speed (E07). I particularly like to work here because if the right approach was taken, you draw the correct path of the patient, generating a sense of pleasure because you realize that everything is going well (E12).

On the other hand, it is realized that the host with risk assessment and classification is not only a source of pleasure since suffering was present in the speeches of the participants as shown in the following category.

\section{Causes of suffering of nurses in the context of host with risk assessment and classification}

The feeling of fear was referred by nurses to perform the hosting, as they recognize that the clinical signs of the patients treated are unstable and in many cases may worsen. Thus, the professional fears classify the patient wrongly, as any inconsistent action may affect the user's health, and may cause irreversible damage: At first I was afraid, I did not know, maybe it was not fear, but insecurity to classify someone wrong or pre-judge the patient (E09). My biggest fear is for the patient to arrive and I did not see, and he die in front of me (E03). The host with risk assessment and classification generates much fear (E06).

Nurses also express feelings of frustration, stress and fatigue related to the intense work process, overcrowding of the unit and sometimes do not succeed the expectations of users as the following lines: Every day the same thing will fatiguing, will causing frustration, anguish. We left slaughtered and apathetic (E04). It is a very large negative charge, the person is already nervous and often blame us, you leave emotionally tired. It is a very stressful job; then the person runs out getting there (E07).

Another triggering factor of suffering to nurses is related to the demands of care repressed of other institutions, mainly of specialized care services and basic health units. Users of these services, in many cases, can not resolve immediate care and seek the emergency services assistance to their health condition: The hospital assists many patients of primary care service that comes without being referenced. If each primary, secondary and tertiary service worked in its line, it would not have this huge demand and the delay to assist (E04). What would improve if there was a counter-reference, forward for primary care the patient that is not life-threatening, but unfortunately, this is not done (E05). We are a secondary hospital, but many problems could be resolved in primary care units, and people are a long time waiting for the assistance here (E06). Many assistance is from basic health units, but people look directly here because they report that the basic unit does not work because it has no medical, burdening our work (E11).

Nurses also report difficulties facing the violent situations, since ten of the respondents reported having suffered some form of violence when carrying out the host with risk assessment and classification: You feel exposed, I have suffered moral violence several times, it is hard to stay in the hosting, we are threatened (E04). I've suffered several times physical and verbal abuse, once a patient threw an oil alcohol because I said he would have to wait for service (E06). I suffered verbal violence; this occurs when you explain that the service will take some time, they do not understand how the hosting works (E08).

Thus, due to the suffering and difficulties experienced daily in professional practice, nurses have developed defensive strategies that assist in the work routine in the host with risk assessment and classification as shown in the following category.

\section{Strategies to deal with the suffering of nurses who perform the host with risk assessment and classification}

Respondents reported some defensive strategies to minimize suffering in the context of hosting with risk assessment and classification, as 
they recognize that the emergency services have peculiarities and the professional needs to have an adequate profile to develop this function: Sometimes there is a nurse to work at all, so we are unable to stay 12 hours at the reception, so we end up delegating to the nursing technician, but we support them, we discussed the cases (E07). The right is to have a nurse in the classification 24 hours, but he is divided because he operates in other sectors (E03).

Another way to deal with the pain reported by nurses is carrying out the turnover: Because we do a scale of 12x36, we split the turn, a professional is six hours and the other for the remaining six hours, because it is a place where people do not want to work for a long time, to be a hard place (E04). The staff is very stressed in the host, then we change (E05). The classification of professionals who work in risk assessment is by switching turns because even those who have a profile and like to host assessment and risk rating report that get too stressed because it is much pressure (E10).

\section{Discussion}

The professional qualifications of nurses result from the concern of these professionals keeping up to date and specialized in their area of expertise as well as the managerial coherence of the institution to scale trained professionals to perform the hosting with risk assessment and classification.

The pleasure and satisfaction that respondents mentioned when hosting with risk classification refer to one of the guidelines of the National humanization policy, which states that the host approach the worker and the user to create the bond that favors health actions be developed ${ }^{(3)}$. Also, they demonstrate that the professional considers the user as a member of his entire health process ${ }^{(1)}$.

The work in healthcare consists of a meeting of subjectivities, which goes far beyond norms, routines or protocols, since it provides an experience exchange relationship, knowledge, and values between user and worker ${ }^{(10)}$. In these relationships, it is presupposed the use of lightweight technologies, which constitute one of the key elements in management, facilitating the production of bonding, acceptance, empowerment and management of the work process ${ }^{(11)}$.

The nurse aims to promote care for the recovery of the individual or minimizing their suffering and when this occurs the feelings of pleasure and gratification provide the reward for work ${ }^{(12)}$. The ability to relieve pain, save lives and to feel useful, can be a source of comfort and satisfaction, which contributes to the feeling of pleasure and promotes a mental balance of health workers ${ }^{(5)}$.

In this sense, the pleasure reported by nurses working in hosting with risk assessment and classification is related to the minimization of the patient's suffering and also assistance for the improvement of the clinical picture. This result was also shown in a survey conducted in the rural municipality of Vale di Rio Pardo-Rio Grande do Sul, with nursing professionals who work in hospital and family health unit in which job satisfaction occurred when professionals eased the suffering of the patient ${ }^{(12)}$.

Through the reports, it is possible that the pleasure in the work of nurses who perform the hosting is associated with the user's well-being, as to meet the patient's needs there is a recognition of their work. The pleasure in the work is associated with creating a context that enables professionals to learn, create, innovate and develop new management strategies for the implementation of their daily tasks. Thus, it opens gaps for interaction and transformation of the work itself, which contributes to the identity of the worker in the social field, generating professional recognition, which is understood as the construction of authenticity at work, motivating the meaning and significance of the chosen profession ${ }^{(5)}$.

On the other hand, there are also feelings of fear and insecurity that are common in professionals who work in urgency and emergency services, since these sectors are imminent unplanned and clinical complications of users. Also, hosting with risk assessment and classification requires constant professional attention and service agility ${ }^{(10,13)}$. 
Therefore, health professionals assigned to work in these services need to be able to act according to the guidelines of clinical protocols and still have manual dexterity, emotional self-control and ease of communication, as they are fundamental requirements for achieving the first service to users ${ }^{(4)}$.

The difficulties experienced by professionals to perform the hosting are from object to nonpleasurable situations that cause suffering at $\operatorname{work}^{(7)}$. These difficulties may be related to the fact that these workers face daily the flaws and limitations of the health care network that interfere with the user assistance resoluteness.

People who seek care in emergency rooms often have come to service frustrated, stressed and other negative feelings that may trigger a conflict with the professional who attends the emergency department. These conflicts can result in increased psychological burden on workers and long-term interfere with their illness ${ }^{(10)}$.

In fact, urgent and emergency services are recognized by some users as the only gateway to the National Health System. Most people who need healthcare in the public system believe that their condition is best treated in hospital services because hospital-centered model persists culturally among the population $^{(14)}$.

This constant search for service demand for other health services causes overcrowding, delays in care, stress overload of users and workers in urgent and emergency services. Overloading is considered by the psychodynamics of work a social pathology, and may be the precursor of repeat injuries and psychosomatic illnesses, and the organization of work is responsible for deciding which professional workload they will face ${ }^{(7)}$.

There is still the difficulty in performing the referral and counter-referral between health services in the existing health care network, due to the failure of communication tools between the institutions and professional awareness of the importance of doing it. This result was also observed in a survey conducted in the emergency room of Porto Alegre - Rio Grande do Sul, with nursing professionals, in which the host with risk assessment and classification was regarded as an "empty speech" because participants studied did not believe that there is resoluteness of referred cases and, therefore, the purpose of the reception was not reached ${ }^{(2)}$.

The disarticulation of the different levels of care health interferes negatively to the institution of host policy and humanization in the Unified Health System. This policy provides the host with risk assessment, and classification is not an isolated act, and there is a link between all health care networks, being internal, external, but also multidisciplinary to ensure responses to the users ${ }^{(3)}$.

Thus, the difficulty in performing the counter reference system contributes to the universality of guidelines of the Unified Health System not being complied, in which the phrase "health is a universal right and duty of the state" without its real appreciation, and many health services do not have sufficient facilities to watch all the demand for care.

Difficulties in carrying out the service, as mentioned above, such as overcrowding and lack of resources, cause limiting the caring capacity of urgent and emergency services and sometimes generates revolt in the population that is waiting to be answered. In the report of the nurse "they do not understand how the host works", the interviewee demonstrates believe that user does not understand the technical look of risk stratification performed in the evaluation, since for many of them, their health condition needs immediate care, starting a conflict between users and professionals, generating the various types of violence $^{(15)}$.

This situation exposes workers to occupational violence, which is defined as any action of one person against another that is related to aggression, offense, injury or humiliation in their work or as a result of it. This type of violence is common in emergency services and professional care, in most cases, they are the main victims, to conduct the first evaluation and 
guidance on the care flow ${ }^{(16-17)}$.

Most respondents reported that had been victims of verbal violence. This type of aggression was also prevalent in a study of 23 nursing professionals, who worked in emergency care service and who have suffered some verbal violence during the development of their work, and the main responsible for these acts were users and caregivers ${ }^{(16)}$.

Violence can have a negative effect on workers' health since the work environment becomes a tense place to cause suffering, stress and anxiety for assaulting professionals ${ }^{(2,16)}$. Professionals create a defensive strategy to minimize such suffering, which is defined by the psychodynamics of work and rules built and run by men behaviors to minimize the perception of pain $^{(7)}$.

Defensive strategies are characterized according to each work situation, with a subtle, ingenious, diverse and inventiveness nature, helping to support workers suffering without becoming ill( ${ }^{(7)}$. These arise when the prescribed work and real work hinder to reconcile both, so the professional develop defense mechanisms to protect themselves from suffering, these can be individual or collective $e^{(6)}$.

One of these strategies is to go back to perform the screening by nursing technicians. This reality where technical level nursing professionals are responsible for performing screening does not occur only in this service; in a study conducted in the emergency room of Porto Alegre, Rio Grande do Sul, nursing technicians are responsible for the initial assessment of patients seen in the service and this assessment is basically on vital signs and note of clinical complaint ${ }^{(15)}$.

Carry out only the screening of users, does not reach the proposal of the National Humanization Policy as the hosting with risk assessment and classification implies as relational technology tool building links, where the host expresses the inclusion of users. Thus, the host with risk assessment and classification should not be practiced only as a form of triage, but it is necessary to qualify the service to users so that this assessment does not work only as a device to achieve the organization of waiting lists ${ }^{(3)}$.

Another defensive strategy used by professionals is the turnover scale, considered effective because it helps a load of deposited stressor agents in the professionals working in the host with risk assessment and classification not so intense. Also, working with the activities of rotation contributes to the professional recognizes all interfaces of the work process in urgent and emergency services and apply the unit management with subsidies to organize the service.

Thus, defensive strategies are only one of the means used by professionals, often unconsciously, to minimize suffering in the workplace. The host with risk assessment and classification is a relatively new strategy that still need implementations and enhancements, as well as awareness of managers, professionals and users about its importance. Professionals who perform this assignment should be valued and supported by the organization to strengthen this important tool for organization of health production process.

However, it is important to note that the implementation of the hosting was a major step forward for the health system in Brazil, as it helped in the organization of service lines in emergency rooms, showing which cases require care of urgency and emergency. Also, it contributed to greater autonomy and sense of professional satisfaction of nurses, as appropriate, responsive and humanized care are important factors for the survival of users.

\section{Conclusion}

The research nurses describe feelings of pleasure and suffering in the work of the host with risk assessment and classification and use of coping strategies to minimize the negative feelings.

The feeling of pleasure came when the professional contributed to the scope of assistance needs of the user. Also, the professional commitment 
to quality of care provided is something pleasurable, especially when displaying the amelioration of the patient's pain.

On the other hand, the limitations in health care resources and health network can cause conflicts with other users and services, resulting in suffering for these professionals due to overload, stress, and fear. Defensive strategies used by these professionals include preparing turnover assistance among nurses to work in risk classification and the delegation that assignment to the technical nursing team.

This study concludes that the hosting with risk assessment and classification is configured as one of the potentially decisive interventions in the reorganization of the work process in the emergency services. However, investments are needed to qualify professionals and structuring the health institutions to consolidate this strategy that contributes to the organization of health care networks and enables users to be assisted with resoluteness and humanization.

\section{Collaborations}

Sakai AM, Rossaneis MA and Haddad MCFL contributed to the text design, analysis, data interpretation, article writing and final approval of the version to be published. Sardinha DSS contributes to the text design, article writing and final approval of the version to be published.

\section{References}

1. Ministério da Saúde (BR). Secretaria de Atenção à Saúde, Núcleo Técnico da Política Nacional de Humanização. HumanizaSUS: documento base para gestores e trabalhadores do SUS. Brasília: Ministério da Saúde; 2008.

2. Dal Pai DMZ, Lautert L. Sofrimento no trabalho de enfermagem: reflexos do "discurso vazio" no acolhimento com classificação de risco. Esc Anna Nery. 2011; 15(3):524-30.
3. Ministério da Saúde (BR). Secretaria de Atenção à Saúde. Política Nacional de Humanização da Atenção e Gestão do SUS. Acolhimento e classificação de risco nos serviços de urgência. Brasília: Ministério da Saúde; 2009.

4. Costa AM, Duro CLM, Lima MADA. Activities of the nurse involved in triage/risk classification assessment in emergency services: an integrative review. Rev Gaúcha Enferm. 2012; 33(4):181-90.

5. Martins JT, Robazzi MLCC, Bobroff MCC. Pleasure and suffering in the nursing group: reflection to the light of Dejour psychodynamics. Rev Esc Enferm USP. 2010; 44(4):1107-11.

6. Dejours C. A loucura do trabalho: estudo de psicopatologia do trabalho. São Paulo: Cortez; 2015.

7. Giongo CR, Monteiro JK, Sobrosa GMR. Psicodinâmica do trabalho no Brasil: revisão sistemática da literatura. Temas Psicol. 2015; 23(4):803-14.

8. Hospital Dr. Anísio Figueiredo. Pronto Socorro. [Internet]. 2014 [citado 2014 maio 20]. Disponível em:http://www.hdaf.pr.gov.br/modules / conteudo/conteudo.php?conteudo=7

9. Bardin L. Análise de conteúdo. Lisboa: Edições 70; 2010.

10. Garcia AB, Dellaroza MSG, Gvozd R, Haddad MCL. 0 sofrer no trabalho: sentimentos de técnicos de enfermagem do pronto-socorro de um hospital universitário. Ciênc Cuidad Saúde. 2013; 12(3):416-23.

11. Adams F, Rodrigues FCP, Fontana RT. The light technologies in the nursing assistance in the units of intensive therapy. Rev Enferm UFPE On line [Internet]. 2011 [cited 2015 dec 13]; 5(spe):41725. Available from: http://www.revista.ufpe.br/ revistaenfermagem/index.php/revista/article/ viewArticle/1366

12. Kessler AI, Krug SBF. Do prazer ao sofrimento no trabalho da enfermagem: o discurso dos trabalhadores. Rev Gaúcha Enferm. 2012; 33(1):49-55. 
13. Dal Pai DMZ, Lautert L, Krug JS. Psicodinâmica e saúde mental do trabalhador de enfermagem: ritmo acelerado e intensificação do fazer. Enferm Foco. 2011; 2(1):38-43.

14. Azevedo ALCS, Pereira AP, Lemos C, Coelho FM, Chaves LDP. Organização de serviços de emergência hospitalar: uma revisão integrativa de pesquisas. Rev Eletr Enferm [periódico na Internet]. 2010 [citado 2014 mai 15]; 12(4):73645. Disponível em: https://www.fen.ufg.br/fen_ revista/v12/n4/v12n4a20.htm
15. Zanelato DM, Dal Pai DMZ. Práticas de acolhimento no serviço de emergência: a perspectiva dos profissionais de enfermagem. Cienc Cuid Saúde. 2010; 9(2):358-65.

16. Vasconcellos IRR, Abreu AMM, Maia EL. Violência ocupacional sofrida pelos profissionais de enfermagem do serviço de pronto atendimento hospitalar. Rev Gaúcha Enferm. 2012; 33(2):16775.

17. Felli VEA. Condições de trabalho de enfermagem e adoecimento: motivos para a redução da jornada de trabalho para 30 horas. Enferm Foco. 2012; 3(4):178-81. 